\title{
Effects of Maize (Zea Mays L.) Hybrids and Nitrogen Application on Striga Infection and Grain Yield under Natural Infestation with the Parasitic Weed Striga hermonthica
}

Reuben Solomon ${ }^{1,2}$, Alpha Y. Kamara ${ }^{1 *}$, Abebe Menkir ${ }^{1}$, David Chikoye ${ }^{1}$, Kamaluddin T. Aliyu ${ }^{1}$, Temitope Ademulegun ${ }^{1}$, Ibrahim B. Mohammed ${ }^{2}$, Abdullahi I. Tofa ${ }^{1}$ and Lucky. O. Omoigui ${ }^{1}$

1 International Institute of Tropical Agriculture (IITA), P.M.B. 5320, Oyo Rd, Ibadan 200211 Nigeria; R.Solomon@cgiar.org (R.S.); A.Kamara@cgiar.org (A.Y.K.); A.Menkir@cgiar.org (A.M.); D.Chikoye@cgiar.org (D.C); K.Tijjani@cgiar.org (K.T.A.); T.Ademulegum@cgiar.org (T.A); A.Tofa@cgiar.org (A.I.T.); L.Omoigui@cgiar.org (L.O.O.)

2 Department of Agronomy, Bayero University, P.M.B. 3011, Kano 700241, Nigeria; ibabamohd@yahoo.co.uk (I.B.M.)

* Correspondence: A.Kamara@cgiar.org; Tel.:_234-803-647-9031 
20 Abstract: Low soil nitrogen status of savanna soils in Nigeria contributes to the persistent Striga hermonthica (Del.) Benth. infestation that limits maize production. The application of nitrogen fertilizer to Striga-resistant hybrids may reduce Striga infection and increase grain yields. This study assessed the performance of maize hybrids at low (30 $\left.\mathrm{kg} \mathrm{ha}^{-1}\right)$ and high (120 $\mathrm{kg} \mathrm{ha}^{-1}$ ) nitrogen application under natural infestation with Striga at Kafin Madaki and Tudun Wada in 2014 and 2015. Results showed that the application of nitrogen at $120 \mathrm{~kg} \mathrm{ha}^{-1}$ reduced number of Striga plants by $59 \%$ compared to application at $30 \mathrm{~kg} \mathrm{~N} \mathrm{ha}^{-1}$ in Kafin Madaki and by $21 \%$ in Tudun Wada. Compared to $30 \mathrm{~kg} \mathrm{~N} \mathrm{ha}^{-1}$, the $120 \mathrm{~kg} \mathrm{~N} \mathrm{ha}^{-1}$ rate also reduced Striga damage rating by $22 \%$ in Kafin Madaki and by $33 \%$ in Tudun Wada across the hybrids. Hybrids 8338-1 (5.3) and OBASUPER 1 (4.3) were the only entries with Striga damage rating greater than 4.5 (SDR > 4.5) when averaged across the nitrogen levels at both locations. Grain yield was 86 and 98\% higher in Kafin Madaki and Tudun Wada, respectively when $\mathrm{N}$ was applied at $120 \mathrm{~kg} \mathrm{~N} \mathrm{ha}^{-1}$ than at $30 \mathrm{~kg} \mathrm{~N} \mathrm{ha}^{-1}$. The hybrids M1124-3 and M1227-14 produced grain yields that were significantly higher than those of the other hybrids in all locations. The hybrid 8338-1 produced the lowest grain yield across locations. Our results showed that, the application of $120 \mathrm{~kg} \mathrm{~N} \mathrm{ha}^{-1}$ to Striga resistant maize hybrids will reduce Striga infection and increase grain yield.

Keywords: Striga infestation; Striga damage; yield loss; nitrogen application 


\section{Introduction}

Maize is regarded as one of the most important staple crops for many sub-Saharan African (SSA) countries [1]. It makes significant contribution in bridging the gap between food demand and supply in SSA because of its high yielding potential, stress-tolerance and wide adaptation to the major agro-ecological zones $[2,3,4]$. Nigeria is the second largest producer of maize in Africa, producing an average of 10.5 million tons per year over the past decade [5]. Despite the importance of maize, yields in Nigeria remained at less than $2 \mathrm{t} / \mathrm{ha}$, which is far below the average global yield of $5.5 \mathrm{t} / \mathrm{ha}[5]$.

In addition to intermittent drought and poor soil fertility [6], Striga is a serious constraint to the productivity of maize and other staple cereals in Nigeria [7-9], and can cause yield losses between 20 to $80 \%$, or total crop failure when infestation is acute $[10,11]$. The increasing incidence of Striga has been attributed to poor soil fertility and structure, intensification of land use through continuous cultivation and an expansion of cereal production $[12,13]$. Yield losses depend on the level of infestation, the soil fertility status, agroclimatic conditions, the plant species, and the genotype grown [14]. Surveys in the Northern Guinea Savannah of Nigeria (NGS) showed that Striga. hermonthica has remained a serious problem, attacking millet, sorghum (Sorghum bicolor L. Moench), maize (Zea mays L.) and upland rice (Oryza sativa L.) $[15,16]$. In northeast Nigeria, over $85 \%$ of the fields planted to maize and sorghum were infested with Striga [16]. Another field study conducted in northern Nigeria showed that Striga incidence range from $0 \%$ to $100 \%$ in farmers' maize fields [7]. The most important Striga species in Nigeria and West Africa at large is S. hermonthica. The parasite impairs host normal growth by developing and attaching their haustoria to the host xylem, hence drawing water and nutrients, resulting in a stunted growth, reduction of biomass and poor grain filling [17].

Several methods have been recommended for the control of Striga in maize. These include the use of Striga-tolerant or resistant maize cultivars [18-20], application of nitrogen particularly for poor soils [8,14,21,22), legume-maize rotation [23-26], herbicide seed coating $[21,27]$. Maize breeders at the International Institute of Tropical Agriculture (IITA) have considered breeding for polygenic resistance to $S$. hermonthica as a viable approach to provide durable protection to the crop against diverse parasite populations [19]. As a result, significant increases in grain yield, coupled with reductions in parasite-induced damage symptoms, and number of emerged parasites have been reported $[19,28,29]$. Significant progress has been 
71 made in the deployment of some extra-early, early, and late maize cultivars that combine resistance/tolerance to Striga with drought tolerance $[19,29]$.

The application of nitrogen has been reported to be effective in reducing Striga infection and damage in maize [30]. Adequate nitrogen, especially urea and cereal-legume rotation, had been reported to be effective in reducing Striga emergence, damage, and increasing dry weight in maize and sorghum [9,13,30]. Most studies however, reported that the effect of nitrogen on Striga infection is only effective at very high doses $[8,13,30]$. Rates between 120 [30] and $280 \mathrm{~kg} \mathrm{~N} \mathrm{ha}^{-1}$ [31] reduced Striga damage on cereal crops, such as maize and sorghum. Kamara et al. [8] also reported significant reductions in the number of emerged Striga at $\mathrm{N}$ application of $120 \mathrm{~kg} \mathrm{~N} \mathrm{ha}^{-1}$ for early-maturing varieties and $60 \mathrm{~kg} \mathrm{~N} \mathrm{ha}^{-1}$ for late maturing varieties in northeast Nigeria. Showemimo et al. [15] reported that a combination of fertilizer between 50 and $100 \mathrm{~kg} \mathrm{~N}$ ha ${ }^{1}$, and some level of Striga tolerance reduced Striga emergence and increased sorghum grain yield. Farmers in Nigeria however, do not generally apply high doses of $\mathrm{N}$ to maize crops because of high cost. This makes it difficult to rely on $\mathrm{N}$ application alone to control Striga infection in maize.

The combination of the use of Striga-resistant or tolerant maize varieties or hybrids with the application of $\mathrm{N}$ fertilizers have been reported to significantly reduce Striga infection and damage in maize. For example, Kim et al. [30] reported that the application of between 120 and $150 \mathrm{~kg} \mathrm{ha}^{-1}$ of $\mathrm{N}$ to Striga-tolerant maize hybrids reduced the number of emerged Striga and Striga damage in maize under artificial infestation. Under natural field infestations, Kamara et al. [8] reported significant reduction of number of emerged Striga and Striga damage on open-pollinated varieties of maize that were bred for resistance to Striga when N was applied at between 60 to $120 \mathrm{~kg} \mathrm{ha}^{-1}$. Striga infection in maize can be managed by integrating appropriate resistant and tolerant maize varieties with adequate $\mathrm{N}$ fertilization.

Past studies on the combined effects of improved maize varieties and $\mathrm{N}$ application on Striga emergence and damage had considered either Striga-tolerant hybrids [29,30] or Strigaresistant/tolerant open-pollinated maize varieties $[8,13]$. Most of the reports on the effects of $\mathrm{N}$ application to Striga-resistant and tolerant maize genotypes on Striga infection and damage in Nigeria have focused on open-pollinated varieties (OPVs) except for the studies of BaduApraku et al. [29] and Kim et al. [30]. Recently, breeders at International Institute of Tropical Agriculture (IITA) have developed several high-yielding modern maize hybrids that are resistant and or tolerant to Striga infection (Abebe Menkir Personal communication). These hybrids were however, evaluated under artificial Striga infestation. Information on their performance under natural infestation of Striga is not known. Moreover, the combined effects 
of these hybrids and $\mathrm{N}$ application are not known. Therefore, the objective of this study was to assess the effect of two $\mathrm{N}$ fertilizer rates on Striga-resistant maize hybrids in fields naturally infested with Striga.

\section{Materials and methods}

\subsection{Description of the Experimental Sites}

Four hybrids combining tolerance to drought with resistance to Striga (DTSTR) developed in the maize breeding program at IITA plus commercial and susceptible hybrid checks were included in the present study (Table 2). The study was conducted at Kafin Madaki (N 10 $42.296^{\prime}$ E $009^{\circ} 46.536^{\prime}$ altitude 623 masl) in the Sudan savanna (SS) of Bauchi State located in the northeast Nigeria, and Tudun Wada, (N11 '13.123' E 008²9.969', altitude 621 masl) in the northern Guinea savanna (NGS) of Kano State located in the northwest Nigeria. The sites were selected based on their known history of endemic high and frequent Striga infestation levels when cereals are planted. The two sites are characterized by mono-modal rainfall distribution. Figure 1 shows total monthly rainfall and monthly average minimum and maximum temperatures for the two experimental sites in 2014 and 2015 recorded using WatchDog 2000 series weather station installed at each site. At Kafin Madaki total annual rainfall was 559 and $880 \mathrm{~mm}$ respectively for 2014 and 2015. Although the rainfall was higher in 2015 the distribution was more uniform in 2014. Average minimum temperature during the season was $22.1{ }^{\circ} \mathrm{C}$ in 2014 and $22.4{ }^{\circ} \mathrm{C}$ in 2015 . Average maximum temperature was $34.7^{\circ} \mathrm{C}$ in 2014 and $35.3{ }^{\circ} \mathrm{C}$ in 2015 . At Tudun Wada, rainfall was higher in $2014(1064 \mathrm{~mm})$ than in $2015(893 \mathrm{~mm})$. However, peak rainfall amount for the 2 years of the experiment was in August while distribution was more normal in 2014. Average maximum temperature was $33.4{ }^{\circ} \mathrm{C}$ in 2014 and $33.8^{\circ} \mathrm{C}$ in 2015 . The temperature was higher around March to May, and then lowered from July in both experimental years.

Soil analysis results for the two locations in Table 1 shows little variation in the soil particle composition of both locations between the experimental years. The soil $\mathrm{pH}$ in Kafin Madaki was moderately acidic (6.0) in 2014 and slightly alkaline (7.1) in 2015. In Tudun Wada, $\mathrm{pH}$ was neutral (6.6) in 2014 and then slightly alkaline (7.3) in 2015. Across the two locations pH was generally lower in 2014 than in 2015. Also, organic carbon was very low at both locations in 2014; 3.2 and $2.4 \mathrm{~g} / \mathrm{kg}$ in 2014 in Kafin Madaki and Tudun Wada respectively and 7.9 and $5.6 \mathrm{~g} / \mathrm{kg}$ in 2015 for Kafin Madaki and Tudun Wada respectively. Total nitrogen is rated low using Esu [32] classification, at both location with Kafin Madaki having $0.3 \mathrm{~g} / \mathrm{kg}$ 
137

138

139

140

141

142

143

144

145

146

147

148

149

150

151

152

153

154

155

156

157

158

159

160

161

162

163

164

165

166

167

while Tudun Wada had $0.19 \mathrm{~g} / \mathrm{kg}$ in 2014. In 2015, the total nitrogen content is rated moderate; 1.05 and $0.40 \mathrm{~g} / \mathrm{kg}$ respectively for Kafin Madaki and Tundun Wada. Available phosphorus is rated very low; with values of 3.39 and $3.70 \mathrm{mg} / \mathrm{kg}$ respectively for Kafin Madaki and Tudun Wada in 2014. The available phosphorus values were moderate, $(13.7 \mathrm{mg} / \mathrm{kg}$ for Kafin Madaki and $7.88 \mathrm{mg} / \mathrm{kg}$ for Tudun Wada) in 2015. Exchangeable cations ( $\mathrm{Ca}, \mathrm{K}$ and $\mathrm{Na}$ ) were also higher in 2015 than in 2014 across the sites. Following Esu [32] fertility rating criteria, exchangeable cations across the sites fall under low fertility class a fertility rating apart from $\mathrm{Mg}$ which is moderate.

\subsection{Experimental Design and Treatments}

The experiment was conducted during the 2014 and 2015 cropping seasons on adjacent pieces of land. Fields previously grown to sorghum were selected based on the level of Striga infestation in the sorghum fields in the previous years. Fields were ploughed and ridged using draught animals. Six maize hybrids and 2 nitrogen rates were compared under natural infestation with S. hermonthica. The experiment was arranged in split plot design with three replications. The main plot consisted of nitrogen rates of 30 and $120 \mathrm{~kg} \mathrm{~N} \mathrm{ha}^{-1}$. The maize hybrids were assigned to the subplot. Each hybrid was planted in four rows of $4 \mathrm{~m}$ length spaced $0.75 \mathrm{~m}$ apart with $0.5 \mathrm{~m}$ spacing between plants in each row. Three maize seeds were sown in a hole of $5 \mathrm{~cm}$ depth. Two weeks after planting, all plants were thinned to two per hill to give a final plant population of 53,333 plants ha ${ }^{-1}$. All plots received $40 \mathrm{~kg} \mathrm{ha}^{-1}$ each of $\mathrm{P}$ as single super phosphate and $\mathrm{K}$ as muriate of potash immediately after planting. All fertilizer was band-applied on ridges. Nitrogen was applied in form of urea in two equal splits for all the treatments a week after sowing (WAS) and the other half at 5 WAS. Immediately after sowing, gramozone (1:1-dimethly-4, 4'-bipyridinium dichloride) was applied at the rate of $280 \mathrm{~g}$ a.i ha'

${ }^{1}$ to control weeds. Hoe weeding was done at 4 WAS. Subsequently, hand pulling of weeds was done regularly to keep the field clean.

\subsection{Measurements}

Striga damage symptoms and numbers of emerged plants were recorded from both locations. Damage symptoms were visually rated on the maize plants from the two middle rows at 10 and 12 WAS using a scale of 1 to 9 , where $1=$ no visible symptoms and $9=$ all leaves completely scorched resulting in premature death [32]. Similarly, Striga count was done by individually counting all emerged Striga plants within the two inner rows of each plot at 12 
WAS and the number converted to per meter square. Maize grain yield was determined by harvesting all the ears of plants in the two middle rows, excluding the last two plants of each row. The ears from each plot were dried, shelled and the percentage grain moisture was determined using a FARMEX MT-16 grain moisture tester (Model HH21 GH350142) from Farmex manufacturers Finland). Grain yield adjusted to $12 \%$ moisture was computed from the shelled grain.

\subsection{Statistical Analysis}

Statistical analysis of the data collected was done with SAS version 9.3 [33]. The data were analysed separately for each location using mixed-model procedure using the PROC Mixed command of SAS. Replication and Year were treated as random effect, whereas nitrogen rates and hybrids were treated as fixed effects in determining the expected mean squares and appropriate F-test. Mean differences of treatments were separated using LSD. Pearson's correlation coefficient between grain yield and Striga related parameters was also computed using PROC CORR of SAS [33].

\section{Results}

In the analysis of variance (Table 3), the effect of year (Y) was significant on all measured traits, except Striga count in Kafin Madaki and Striga damage rating in Tudun Wada. Nitrogen had a significant effect on all traits recorded in both locations, whereas Nitrogen $(\mathrm{N})$ $\times$ Year $(\mathrm{Y})$ interaction had significant effect only on grain yield in the two locations. Differences among hybrids $(\mathrm{H})$ and the hybrid $\times$ year interaction were significant for all traits, except the hybrid $\times$ year interaction for Striga damage rating in both locations. The $\mathrm{H} \times \mathrm{N}$ interaction was only significant for total dry matter and grain yield in both locations. The $\mathrm{H} \times$ $\mathrm{Y} \times \mathrm{N}$ were significant for total dry matter in Kafin Madaki and for grain yield in both locations.

The application of nitrogen at the rate of $120 \mathrm{~kg} \mathrm{ha}^{-1}$ reduced the number of emerged Striga plants by $59 \%$ in Kafin Madaki and by $21 \%$ in Tudun Wada compared to the application of $30 \mathrm{~kg} \mathrm{~N} \mathrm{ha}^{-1}$ (Table 4). Among the hybrids, OBASUPER 1 and 8338-1 recorded larger number of emerged Striga plants than the new DTSTR hybrids at the two locations. The differences among the new hybrids were not significant in Kafin Madaki. In Tudun Wada, the number of emerged Striga counted on hybrid M1227-17 was significantly higher than those counted on other DTSTR hybrids (Table 4). 
Striga damage rating was significantly affected by nitrogen level and hybrids at both locations. On the average, increasing nitrogen application from 30 to $120 \mathrm{~kg} \mathrm{ha}^{-1}$ significantly reduced the Striga damage rating by $22 \%$, in Kafin Madaki and by $33 \%$ in Tudun Wada. The Striga damage rating was highest on the susceptible hybrid 8338-1 at both locations. The new DTSTR hybrids had damage ratings that were significantly lower than the commercial hybrid (OBASUPER 1) and the susceptible hybrid 8338-1 checks at the two locations. Differences among the new DTSTR hybrids in Striga damage rating were not significant. The susceptible hybrids 8338-1 and OBASUPER 1 sustained Striga damage symptoms exceeding 4.5 across the two levels of nitrogen (Table 4) in both sites.

Nitrogen application increased total dry matter and grain yields of the hybrids in both locations. Increasing nitrogen application from $30 \mathrm{~kg} \mathrm{ha}^{-1}$ to $120 \mathrm{~kg} \mathrm{ha}^{-1}$ increased total dry matter by $37 \%$ at Kafin Madaki and by $46 \%$ at Tudun Wada (Table 4). Total dry matter and grain yield differed significantly among the hybrids at both locations. The hybrid 8338-1 produced the lowest total dry matter and grain yields at both levels of nitrogen application in the two locations. The total dry matter produced by the new DTSTR hybrids was 2 times higher than that produced by the hybrid 8338-1 at both locations. The commercial hybrid (OBASUPER 1) produced total dry matter that did not differ significantly from those produced by the new DTSTR hybrids at both locations. The response of total dry matter to $\mathrm{N}$ application varied with the hybrid. When $\mathrm{N}$ was applied at $30 \mathrm{~kg} \mathrm{~N}^{-1}$ in Kafin Madaki, M1124-3 produced the highest total dry matter, whereas M1227-14 produced the highest total dry matter at $120 \mathrm{~kg} \mathrm{ha}^{-1}$. The hybrid M1124-3 produced the highest total dry matter at $\mathrm{N}$ application of $30 \mathrm{~kg} \mathrm{ha}^{-1}$ at Tudun Wada, while OBASUPER 1 produced the highest total dry matter at 120 $\mathrm{kg} \mathrm{N} \mathrm{ha}{ }^{-1}$. Grain yield increased by $87 \%$ in Kafin Madaki and by $98 \%$ in Tudun Wada when the application of nitrogen increased from 30 to $120 \mathrm{~kg} \mathrm{ha}^{-1}$. The new DTSTR hybrids produced grain yields that were significantly higher than those of the susceptible (8338-1) and commercial (OBASUPER1) hybrid when nitrogen was applied at either 30 or $120 \mathrm{~kg} \mathrm{ha}^{-1}$. Grain yield response to $\mathrm{N}$ application varied with $\mathrm{N}$ rates at both locations. At each location, hybrid M1227-14 produced he highest grain yield at $\mathrm{N}$ application rate of $30 \mathrm{~kg} \mathrm{ha}^{-1}$ though not significantly different from those of the other DTSTR hybrids. Hybrid M1124-3 produced the highest grain yield at nitrogen application of $120 \mathrm{~kg} \mathrm{ha}^{-1}$.

\section{Discussion}

Evaluation of maize under natural infestation are considered important to confirm performance and effects of Striga parasitism [8]. Screening for Striga resistance under natural 
231 infestation can prove useful when artificial infestation is not effective due to reduction in

232

233

234

235

236

237

238

239

240

241

242

243

244

245

246

247

248

249

250

251

252

253

254

255

256

257

258

259

260

261

262

263

264 inoculum load and desirable growing conditions [34]. As the soils at the two sites were low in organic matter, total $\mathrm{N}$ and available $\mathrm{P}$, these could contribute to high Striga infestation. Poor soil fertility and moisture stress in the savanna soils are usually associated with high levels of Striga infestation [7,6]. Nitrogen application at $120 \mathrm{~kg} \mathrm{ha}^{-1}$ reduced Striga emergence at the two sites, consistent with the findings of several authors who reported reduced Striga infestation when $\mathrm{N}$ was applied at high doses [8,11,30,35]. According to Yoneyama et al. [36], cereals such as sorghum, maize, and rice produce high amounts of Strigolactones that ultimately stimulate the germination of Striga seeds when soils are deficient in N and P. High $\mathrm{N}$ application also reduced Striga damage in the hybrids, corroborating the findings of Kamara et al. [8], and Kim et al. [30] who reported the reduction of Striga damage symptoms when N is applied at high doses. Our results show that although N application reduced Striga infection and damage in maize hybrids, high doses may be needed for $\mathrm{N}$ to be more effective in reducing the Striga damage. Kamara et al. [8], and Kim et al. [30] also suggested that high doses of N are needed for effective suppression of Striga infection and damage in maize crops. The results clearly showed that the use of resistant varieties in combination with high rates of $\mathrm{N}$ fertilizer provided much higher yields than use of susceptible hybrids in Striga infested fields.

In this study, the hybrids 8338-1 and OBASUPER1 had Striga counts that were higher than those of the new hybrids combining tolerance to drought with resistance to Striga. The hybrid 8338-1 recorded higher damage scores than OBASUPER1 and the new DTSTR hybrids, consistent with the findings of Kamara [8] and Menkir and Kling [28]. These authors concluded that whereas 8338-1 is susceptible to Striga, OBASUPER1 is tolerant to Striga infection. It is interesting to note that hybrids bred for tolerance to Striga allow more seed production and high emergence of the parasite with little damage and reduction in grain yield [8].

The lower number of emerged Striga on the resistant hybrids was mainly because they were bred for reduced Striga emergence possibly because resistant varieties produce little or no amounts of the Striga-germination stimulant Strigol [10 ]. As expected N application at 120 $\mathrm{kg} \mathrm{ha}^{-1}$ significantly increased total dry matter and grain yield of all the hybrids at the two locations, confirming reports from other authors that indicate $\mathrm{N}$ is a major limiting nutrient for maize in the Nigeria savannas. Kamara et al. [8] and Kamara et al. [24] reported significant response of maize cultivars to added $\mathrm{N}$ in the Nigerian savannas. Oikeh [37] reported yield increase of $130 \%$ with application of $\mathrm{N}$ to maize. Across $\mathrm{N}$ rates, the new DTSTR hybrids produced grain yields that were $65 \%$ higher than the Striga susceptible hybrid 8338-1 at the two locations, and 23\% and 13\% higher in Kafin Madaki and in Tudun Wada, respectively 
265 than the commercial hybrid OBASUPER1. The new DTSTR hybrids were bred under

266

267

268

269

270

271

272

273

274

275

276

277

278

279

280

281

282

283

284

285

286

287

288

289

290

291

292

293

294

295

296

297 controlled drought stress and artificial Striga infestation and were selected for low Striga emergence and damage (A. Menkir, personal communication). Our results show that varieties or hybrids that are bred for low Striga emergence and damage produced higher grain yields in fields naturally infested with Striga, consistent with findings of Kamara [8]. In on-farm soybean maize rotation experiment in northern Nigeria, Kamara et al. [21] reported that continuously grown Striga-resistant maize varieties produced grain yields similar to that of Striga-resistant maize variety grown after soybean but had higher grain yields than the local susceptible maize hybrids. The higher dry matter and grain yields recorded in the new DTSTR hybrids may be due to the combined effects of N application and lower Striga infection and damage.

\section{Conclusion}

Results from the field study showed a reduction in Striga infestation and damage when we increased $\mathrm{N}$ application rates from 30 to $120 \mathrm{~kg} \mathrm{ha}^{-1}$ for all maize varieties. The new DTSTR hybrids supported fewer emerged Striga plants, sustained lower damage scores and produced higher dry matter and grain yields than the susceptible and commercial hybrids. The application of $\mathrm{N}$ at the recommended rate of $120 \mathrm{~kg} \mathrm{ha}^{-1}$ in combination with DTSTR hybrids can reduce Striga damage and increase grain yield. We conclude that farmers can get better return on their investment when they plant DTSTR hybrids along with optimal level of nitrogen application.

Author Contributions: Conceptualization, A.Y.K., A.M., D.C., L.O.O., I.B.M. and R.S.; methodology, A.Y.K., A.M., and R.S.; formal analysis, A.I.T., K.T.A., T.A. and R.S.; field experimentation, R.S., A.I.T., and A.Y.K.; resources, A.Y.K., D.C., and A.M.; data curation, R.S., A.I.T., T.A., and K.T.A.; writing-original draft preparation, R.S., A.Y.K and K.T.A.; writing-review and editing, L.O.O., A.I.T., A.Y.K., and A.M.; supervision, A.Y.K. and I.B.M.; funding acquisition, A.Y.K., D.C., and A.M. All authors have read and agreed to the published version of the manuscript.

Funding. This research was funded by Bill and Melinda Gates Foundation, grant number: OPP1006185.

Acknowledgements. The authors are thankful to the field technicians for managing the trials. 
298

299

300 
301

302

303

304

305

306

307

308

309

310

311

312

313

314

315

316

317

318

319

320

321

322

323

324

325

326

327

328

329

330

331

332

333

334

\section{References}

1. Ekpa, O.; Palacios, R.; Natalia, K.; Gideon, F.; Vincenzo, L.A. Sub-Saharan African maize-based foods: Technological perspectives to increase the food and nutrition security impacts of maize breeding programmes. Global Food Security 2018, 17. 10.1016/j.gfs.2018.03.007.

2. Adnan, A.A.; Jibrin, J.M.; Kamara, A.Y.; Abdulrahman, B.L.; Shaibu, A.S. Using CERES-Maize model to determine the nitrogen fertilization requirements of early maturing maize in the Sudan savanna of Nigeria. J. Plant Nutr. 2017, 40, 1066-1082.

3. Kamara, A.Y., Ewansiha S.U.; Tofa A.I. Yield, N uptake and N utilization of early maturing, drought and Striga-tolerant maize varieties under low $\mathrm{N}$ conditions, Commun. Soil Sci. Plant Anal. 2019, 50, 373-387.

4. Rurinda, J.; Mapfumo, P.; van Wijk, M.T.; Mtambanengwe, F.; Rufino, M.C.; Chikowo, R.; Giller, K.E. Comparative assessment of maize, finger millet and sorghum for household food security in the face of increasing climatic risk. Eur. J. Agron. 2014, 55, 29-41.

5. Food and Agriculture Organization of the United Nations (FAOSTAT). Available online: faostat3.fao.org/download/Q/QC/E (accessed on 1st February 2019).

6. Kamara, A.Y.; Ewansiha, S.U.; Menkir, A. Assessment of nitrogen uptake and utilization in drought tolerant and Striga resistant tropical maize varieties. Arch. Agron. Soil Sci. 2014, 60(2), 195-207.

7. Ekeleme, F.; Jibrin, J.M.; Kamara, A.Y.; Oluoch, M.; Samndi, A.M.; Fagge, A.A. Assessment of the relationship between soil properties, Striga hermonthica infestation and the on-farm yields of maize in the dry savannas of Nigeria. Crop Prot. 2014, 66, 90-97.

8. Kamara, A.Y.; Ekeleme, F.; Omoigui, L.; Menkir, A.; Chikoye, D.; Dugje, I.Y.; Abdoulaye, T.; Amaza, P. Influence of nitrogen fertilization on the performance of early and late maturing maize varieties under natural infestation with Striga hermonthica (Del.) Benth. Arch. of Agron. Soil Sci. 2009, 55(2), 125-145.

9. Kureh, I.; Kamara, A.Y.; Tarfa, B. "Influence of cereal legume rotation on Striga control and maize grain yield in farmers' fields in the Northern Guinea Savanna of Nigeria," J. Agric. Rural Dev. Trop. Subtrop. 2006, 107, 41-54.

10. Ejeta, G. "The Striga scourge in Africa: A growing pandemic," in Integrating New Technologies for Striga Control: Towards ending the witchhunt. Eds. G. Ejeta and J. Gressel (Singapore: World Scientific Publishing Co., Pte, Ltd), 2007, 3-16. 
335 11. Oswald, A.; Ransom, J.K. Striga control and improved farm productivity using crop rotation. Crop Prot. 2001, 20, 113-120.

12. Rodenburg, J.; Bastiaans, L.; Weltzien, E.; Hess, D.E. How can selection for Striga resistance and tolerance in sorghum be improved? Field Crop. Res. 2005, 93, 34-50.

13. Van Ast, A.; Bastiaans, L.; Katile, S. Cultural control measures to diminish sorghum yield loss and parasite success under Striga hermonthica infestation. Crop Prot. 2005, 24, 1023-1034.

14. Kamara, A.Y.; Menkir, A.; Chikoye, D.; Omoigui, L. O.; Ekeleme, F. Cultivar and nitrogen fertilization effects on Striga infestation and grain yield of early maturing tropical maize. Maydica 2007, 52, 415-423.

15. Showemimo, F.A.; Kimbeng, C.A.; Alabi, S.O. Genotypic response of sorghum cultivars to nitrogen fertilization in the control of Striga hermonthica. Crop Prot. 2002, $21,867-870$.

16. Dugje, I.Y.; Kamara, A.Y.; Omoigui, L.O. Infestation of crop fields by Striga species in the savanna zones of northeast Nigeria. Afr. Agric. Ecosyst. Environ. 2006, 116, $251-254$.

17. Gurney, A.L.; Grimaneli, D.; Kanampiu, F.; Hoisington, D.; Scholes, J.D.; Press, M.C. Do hermonthica (Del.) Benth in a tropical maize population. Crop Sci. J. 2002, 47, 674-684.

18. Menkir, A.; Crossa, J.; Meseka, S.; Bossey, B.; Ado, S.G.; Obengantiwi, K, Chabi, G.; Yallou, N.; Coulibaly, M.; Olaoye, G.; Haruna, A. Comparative performance of top-cross maize hybrids under managed drought stress and variable rainfed environments. Euphytica 2016, 212, 455-472.

19. Menkir, A.; Meseka, S. Genetic improvement in resistance to Striga in tropical maize hybrids. Crop Sci. J. 2019, 59, 2484-2497.

20. Badu-Apraku, B.; Menkir, A.; Ajala, S.O.; Akinwale, R.O.; Oyekunle, M.; ObengAntwi, K. Performance of tropical early maturing maize cultivars in multiple stress environments. Can. J. Plant Sci. 2011, 90, 831-852.

21. Kamara, A.Y.; Menkir, A.; Chikoye, D.; Solomon, R.; Tofa, A.I.; Omoigui, L.O. Seed dressing maize with Imazapyr to control Striga hermonthica in farmers' fields in the Savannas of Nigeria. Agric. 2020, 10, 83.

22. Kim, S.K; Adetimirin, V.O. Response of tolerant and susceptible maize varieties to timing and rate of nitrogen under Striga hermonthica infestation. Agron. J. 1997, 89, $38-44$. 
23. Carsky, R.J.; Berner, D.K.; Oyewole, B.D.; Dashiell, K.; Schulz, S. Reduction of Striga hermonthica parasitism on maize using soybean rotation. Int. J. Pest Manag. 2000, 46, 115-120.

24. Kamara, A.Y.; Menkir, A.; Ajala, S.O.; Kureh, I. Performance of diverse maize genotypes under nitrogen deficiency in the northern Guinea savanna of Nigeria. Expt. Agric. 2005, 41, 199-212.

25. Ellis-Jones J.; Schulz, S.; Douthwaite, B.; Hussaini, M.A.; Oyewole, B.D.; Olanrewaju, A.S.; White, R. An assessment of integrated Striga hermonthica control and early adoption by farmers in northern Nigeria. Expt. Agric. 2004, 40, 353-368.

26. Franke, A.C.; Ellis-Jones, J.; Tarawali, G.; Schulz, S.; Hussaini, M.A.; Kureh, I.; Olanrewaju, A.S. Evaluating and scaling-up integrated Striga hermonthica control technologies among farmers in northern Nigeria. Crop Prot. 2006, 25(8), 868-878.

27. Kanampiu, F.K.; Ransom, J.K.; Gressel, J. Imazapyr seed dressings for Striga control on acetolactate synthase target-site resistant maize. Crop Prot. 2001, 20, 885-895.

28. Menkir, A.; Kling, J.G. Response to recurrent selection for resistance to (Del.) Benth in a tropical maize population. Crop Sci. 2007, 47(2), 674-682.

29. Badu-Apraku, B.; Lum, A.F.; Fakorede, M.A.B.; Menkir, A.; Chabi, Y.; Thé, C.; Abdulai, M.; Jacob, S.; Agbaje, S. Performance of cultivars derived from recurrent selection for grain yield and Striga resistance in early maize. Crop Sci. 2008, 48, 99112 .

30. Kim, S.K., Adetimirin, V.O.; Akintunde, A.Y. Nitrogen effects on Striga hermonthica infestation, grain yield, and agronomic traits of tolerant and susceptible maize hybrids. Crop Sci. 1997, 37, 711-716.

31. Robinson, E.L.; Dowler, C.C. Cultural and edaphic aspects of witchweed control. pp. 99-106. In: P.F. Sand (Ed.), Witchweed research and control in the United States. Monogr. 5. Weed Science Society of America, Champagne, Il., USA. 1990.

32. Esu, I.E. Detailed Soil Survey of NIHORT Farm at Bunkure Kano State, Nigeria; Ahmadu Bello University Zaria: Kaduna, Nigeria. 1991.

33. SAS Institute. Statistical Analysis Software (SAS) user's guide. SAS Institute, Inc. Cary, NC, USA, 2014.

34. Kim, S.K. Genetics of maize tolerance of Striga hermonthica. Crop Sci. 1991, 34, 900907. 
401 35. Emechebe, A.; Ellis-Jones, J.; Schulz, S.; Chikoye, D.; Douthwaite, B.; Kureh, I.; Tarawali, G.; Hussaini, M.; Kormawa, P.; Sanni, A. Farmers' perception of the Striga problem and its control in Northern Nigeria. Expet. Agric. 2014, 40, 215-232.

404

36. Yoneyama, K.; Xie, X.; Kim, H.; Kisugi, T.; Nomura, T.; Sekimoto, H.; Yokota, T.;

405

Yoneyama, K. How do nitrogen and phosphorus deficiencies affect Strigolactone

406 production and exudation? Planta 2012, 235, 197-207.

407

408

37. Oikeh, S.O.; Carsky, R.J.;.Kling, G.; Chude, V.O.; Horst. W.J. Differential N uptake by maize cultivars and soil nitrate dynamics under $\mathrm{N}$ fertilization in West Africa.

410 Agric. Ecosyst. Environ. 2003, 100, 181-191. 


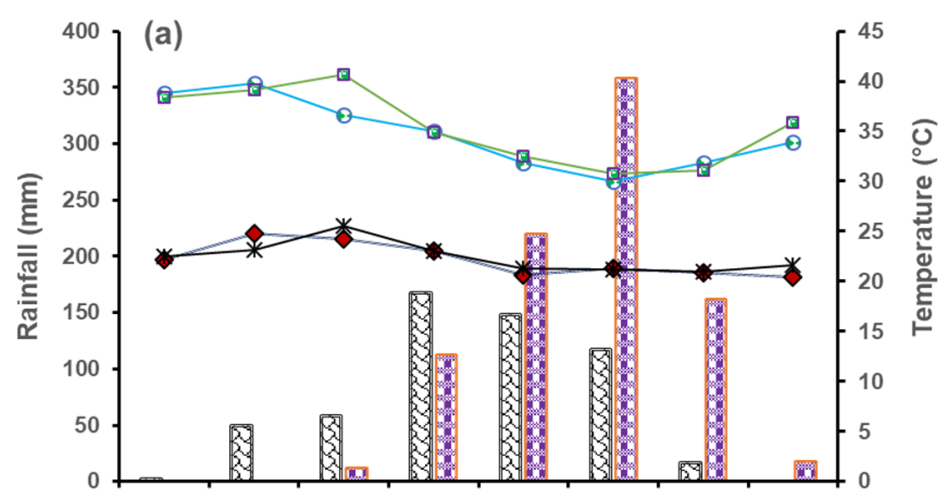

411

412

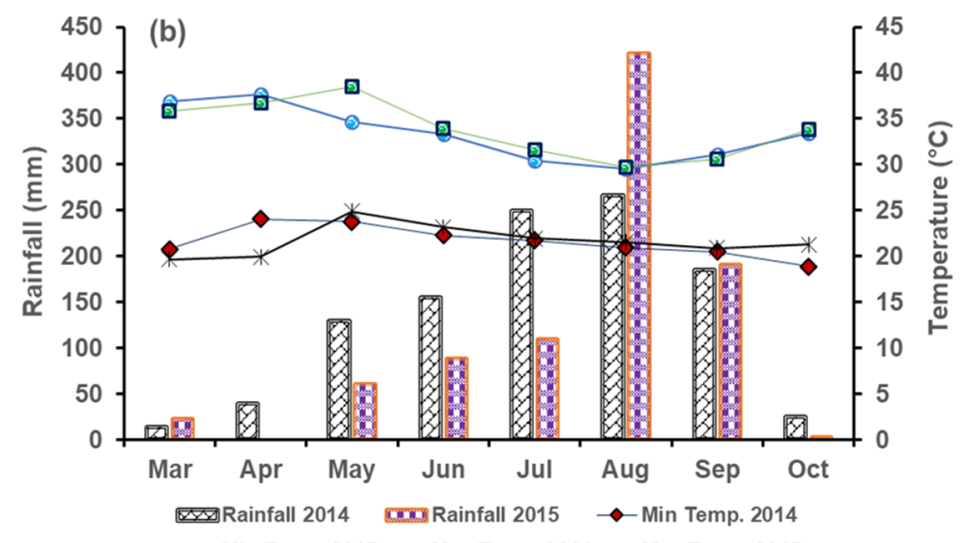

413 Figure 1. Rainfall and temperature of (a) Kafin Madaki and (b) Tudun Wada experimental 414 sites for 2014 and 2015 seasons

415 
416

Table 1. Physico-Chemical properties of soils of the experimental sites.

\begin{tabular}{|c|c|c|c|c|}
\hline \multirow[t]{2}{*}{ Soil properties } & \multicolumn{2}{|c|}{ Kafin Madaki } & \multicolumn{2}{|c|}{ Tudun Wada } \\
\hline & 2014 & 2015 & 2014 & 2015 \\
\hline \multicolumn{5}{|c|}{ Mechanical analysis $(0-15 \mathrm{~cm})$} \\
\hline Sand $(g / k g)$ & 793 & 790 & 776 & 770 \\
\hline Silt (g/kg) & 122 & 120 & 78 & 80 \\
\hline Clay $(g / k g)$ & 85 & 90 & 146 & 150 \\
\hline Textural class & Sandy-loam & Sandy-loam & Sandy-loam & Sandy-loam \\
\hline \multicolumn{5}{|l|}{ Chemical analysis } \\
\hline $\mathrm{pH}$ in $\left(\mathrm{H}_{2} \mathrm{O}\right)$ & 6.0 & 7.1 & 6.6 & 7.3 \\
\hline Organic Carbon $(\mathrm{g} / \mathrm{kg})$ & 3.2 & 7.9 & 2.4 & 5.6 \\
\hline Total N (g/kg) & 0.3 & 1.05 & 0.19 & 0.40 \\
\hline Available P (mg/kg) & 3.39 & 13.70 & 3.70 & 7.88 \\
\hline \multicolumn{5}{|c|}{ Exchangeable bases (C mol (+) kg-1 $)$} \\
\hline $\mathrm{Ca}$ & 1.06 & 1.00 & 1.98 & 1.92 \\
\hline $\mathrm{Mg}$ & 0.53 & 0.25 & 0.60 & 1.17 \\
\hline $\mathrm{K}$ & 0.21 & 0.30 & 0.20 & 0.26 \\
\hline $\mathrm{Na}$ & 0.09 & 0.06 & 0.11 & 0.07 \\
\hline CEC & 1.98 & 4.80 & 2.77 & 4.00 \\
\hline
\end{tabular}

417

418

419 


\begin{tabular}{lllll}
\hline \multicolumn{4}{l}{ Table 2.} & Characteristics of maize hybrids used in the study. \\
\hline Entry & Hybrid name & Colour & Seed size & Reaction to Striga \\
1 & M1124-3 & White & large & Striga resistant and drought tolerant \\
2 & M1124-4 & White & medium & Striga resistant and drought tolerant \\
3 & M1227-14 & White & large & Striga resistant and drought tolerant \\
4 & M1227-17 & White & large & Striga resistant and drought tolerant \\
5 & OBASUPER 1 & White & medium & Commercial hybrid \\
6 & $8338-1$ & White & small & Susceptible hybrid \\
\hline
\end{tabular}


Table 3. P values showing effects of year, nitrogen level, hybrids and their interactions on Striga count, Striga damage rating, total dry matter and grain yield in Kafin Madaki and Tudun Wada.

\begin{tabular}{|c|c|c|c|c|c|c|c|c|}
\hline \multicolumn{9}{|c|}{$\begin{array}{l}\text { Table 3. P values showing effects of year, nitrogen level, hybrids and their interactions on Striga count, Striga damage } \\
\text { rating, total dry matter and grain yield in Kafin Madaki and Tudun Wada. }\end{array}$} \\
\hline \multirow[b]{2}{*}{ Sources of Variation } & \multicolumn{4}{|c|}{ Kafin Madaki } & \multicolumn{4}{|c|}{$\begin{array}{c}\text { Tudun Wada } \\
\end{array}$} \\
\hline & $\begin{array}{c}\text { Striga } \\
\text { count } \\
\mathrm{m}^{-2}\end{array}$ & $\begin{array}{c}\text { Striga } \\
\text { damage } \\
\text { Rating }\end{array}$ & $\begin{array}{c}\text { Total dry } \\
\text { matter } \\
\mathbf{m}^{-2} \\
\end{array}$ & $\begin{array}{c}\text { Grain } \\
\text { Yield } \\
\left(\mathrm{kg} \mathrm{ha}^{-1}\right)\end{array}$ & $\begin{array}{c}\text { Striga } \\
\text { count } \\
\mathrm{m}^{-2}\end{array}$ & $\begin{array}{c}\text { Striga } \\
\text { damage } \\
\text { Rating }\end{array}$ & $\begin{array}{c}\text { Total dry } \\
\text { matter } \\
\text { m }^{-2} \\
\end{array}$ & $\begin{array}{c}\text { Grain } \\
\text { Yield } \\
\left(\mathrm{kg} \mathrm{ha}^{-1}\right)\end{array}$ \\
\hline Year $(Y)$ & 0.2375 & 0.0009 & $<.0001$ & 0.0417 & $<.0001$ & 0.5286 & 0.0034 & $<.0001$ \\
\hline Nitrogen Level (N) & $<.0001$ & $<.0001$ & $<.0001$ & $<.0001$ & $<.0001$ & $<.0001$ & $<.0001$ & $<.0001$ \\
\hline $\mathrm{Y} \times \mathrm{N}$ & 0.1167 & 0.6411 & 0.5208 & $<.0001$ & 0.3597 & 0.211 & 0.4157 & $<.0001$ \\
\hline Hybrid (H) & $<.0001$ & $<.0001$ & $<.0001$ & $<.0001$ & $<.0001$ & $<.0001$ & $<.0001$ & $<.0001$ \\
\hline $\mathrm{H} \times \mathrm{Y}$ & 0.0489 & 0.6907 & 0.0013 & 0.0001 & 0.0022 & 0.5786 & 0.0019 & $<.0001$ \\
\hline $\mathrm{H}$ x N & 0.4659 & 0.1638 & 0.3407 & 0.0421 & 0.899 & 0.3032 & 0.3315 & 0.0025 \\
\hline $\mathrm{H} \times \mathrm{Y} \times \mathrm{N}$ & 0.2118 & 0.8867 & 0.0394 & 0.0005 & 0.7472 & 0.7557 & 0.5949 & 0.01 \\
\hline
\end{tabular}

19

(2)

.

.

.

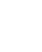


Table 4. Effect of hybrid and nitrogen level on Striga count, Striga damage rating, total dry matter and grain yield in Kafin Madaki and Tudun Wada

\begin{tabular}{|c|c|c|c|c|c|c|c|c|c|c|c|c|}
\hline \multirow[t]{2}{*}{ Hybrids } & \multicolumn{3}{|c|}{$\begin{array}{c}\text { Striga count } \\
\mathbf{m}^{-2}\end{array}$} & \multicolumn{3}{|c|}{$\begin{array}{c}\text { Striga damage } \\
\text { Rating }\end{array}$} & \multicolumn{3}{|c|}{$\begin{array}{c}\text { Total dry matter } \\
\mathbf{m}^{-2}\end{array}$} & \multicolumn{3}{|c|}{$\begin{array}{c}\text { Grain Yield } \\
\left(\mathrm{kg} \mathrm{ha}^{-1}\right)\end{array}$} \\
\hline & 30 & 120 & Mean & 30 & 120 & Mean & 30 & 120 & Mean & 30 & 120 & Mean \\
\hline & \multicolumn{12}{|c|}{ Kafin Madaki } \\
\hline M1124-3 & 6.8 & 1.7 & 4.3 & 4.8 & 3.0 & 3.9 & 938.9 & 1216.1 & 1077.5 & 3425.6 & 7073.8 & 5249.7 \\
\hline M1124-4 & 2.5 & 1.7 & 2.1 & 4.3 & 3.2 & 3.8 & 910.8 & 1103.6 & 1007.2 & 3462.7 & 6349.6 & 4906.1 \\
\hline M1227-14 & 3.3 & 1.0 & 2.2 & 4.2 & 3.3 & 3.8 & 865.2 & 1333.5 & 1099.3 & 3919.8 & 6647.6 & 5283.7 \\
\hline M1227-17 & 4.7 & 1.5 & 3.1 & 4.3 & 3.0 & 3.7 & 791.8 & 1136.0 & 963.9 & 3447.4 & 6178.8 & 4813.1 \\
\hline $8338-1$ C) & 14.3 & 6.8 & 10.6 & 5.7 & 4.8 & 5.3 & 342.3 & 637.8 & 490.0 & 1866.7 & 4265.9 & 3066.3 \\
\hline OBASUPER1 C) & 17.0 & 7.7 & 12.3 & 4.3 & 4.2 & 4.3 & 757.2 & 870.4 & 813.8 & 2984.5 & 5209.1 & 4096.8 \\
\hline Mean & 8.1 & 3.4 & & 4.6 & 3.6 & & 767.7 & 1049.6 & & 3184.4 & 5954.1 & \\
\hline LSD H & 2.6 & & & 0.6 & & & 162.1 & & & 441.6 & & \\
\hline LSD N & 1.5 & & & 0.4 & & & 93.6 & & & 255.0 & & \\
\hline \multirow[t]{2}{*}{ LSD H x N } & $3.6 \mathrm{~ns}$ & & & $0.9 \mathrm{~ns}$ & & & $224.5 \mathrm{~ns}$ & & & 611.8 & & \\
\hline & \multicolumn{12}{|c|}{ Tudun Wada } \\
\hline M1124-3 & 2.5 & 1.3 & 1.9 & 5.0 & 3.2 & 4.1 & 772.5 & 980.8 & 876.6 & 3478.5 & 7553.1 & 5515.8 \\
\hline M1124-4 & 2.0 & 0.3 & 1.2 & 4.7 & 3.7 & 4.2 & 653.7 & 917.2 & 785.5 & 2802.4 & 5508.5 & 4155.4 \\
\hline M1227-14 & 2.0 & 0.3 & 1.2 & 4.7 & 2.8 & 3.8 & 752.5 & 996.6 & 874.5 & 4000.7 & 6662.5 & 5331.6 \\
\hline M1227-17 & 4.8 & 2.7 & 3.8 & 5.3 & 3.7 & 4.5 & 654.0 & 1040.2 & 847.1 & 3447.6 & 5774.7 & 4611.1 \\
\hline 8338-1 C) & 13.0 & 8.3 & 10.7 & 7.0 & 4.5 & 5.8 & 298.8 & 505.9 & 402.4 & 1551.9 & 4394.8 & 2973.4 \\
\hline OBASUPER1 C & 12.7 & 6.0 & 9.3 & 5.7 & 3.8 & 4.8 & 673.7 & 1115.2 & 894.5 & 2791.7 & 5889.3 & 4340.5 \\
\hline Mean & 6.2 & 3.2 & & 5.4 & 3.6 & & 634.2 & 926.0 & & 3012.1 & 5963.8 & \\
\hline LSD H & 1.7 & & & 0.6 & & & 129.1 & & & 408.9 & & \\
\hline LSD N & 1.0 & & & 0.4 & & & 74.6 & & & 236.1 & & \\
\hline LSD $\mathrm{H} \times \mathrm{N}$ & $2.4 \mathrm{~ns}$ & & & $0.8 \mathrm{~ns}$ & & & $178.9 \mathrm{~ns}$ & & & 566.4 & & \\
\hline
\end{tabular}


423

424 
425

426 